\title{
HERITABILITY AND SELECTION ON CLUTCH SIZE IN DARWIN'S MEDIUM GROUND FINCHES (GEOSPIZA FORTIS)
}

\author{
H. LISLE GiBBS ${ }^{1}$ \\ Museum of Zoology and Department of Biology, The University of Michigan, \\ Ann Arbor, $M I 48109$
}

\begin{abstract}
I studied the causes of variation and selection on clutch size in a population of Darwin's Medium Ground Finches (Geospiza fortis) on Isla Daphne Major, using data collected over a nineyear period (1976-1984). Quantitative-genetic analyses were carried out using the first clutch laid by a female in a given year. I used both unadjusted clutch-size values and values adjusted for between-year differences in mean clutch size for repeatability and regression analyses. Repeatability of clutch size was small $(\leq 8 \%)$ and nonsignificant in all cases. Sib-sib analyses and parent-offspring regressions gave no evidence of a significant additive genetic component to clutch-size variation. Slopes of mother-daughter regressions were actually negative, suggesting possible maternal effects of mother's clutch size on daughter's clutch size. There was a small positive relationship between female age and clutch size but no effect of male or female body size or of large-scale differences in habitat quality on clutch size. Selection on clutch size was generally directional and positive: in almost all years in which successful breeding occurred, large clutches tended to fledge more chicks and produce more young surviving to the following year, possibly because there was no trade-off between clutch size and the weights of individual chicks at fledging. Thus, sustained directional selection for large clutch size may have reduced additive genetic variation in clutch size to low levels in this population. The size of a female's clutch may be primarily determined by unidentified proximate environmental factors which vary from year to year, rather than by any long-term optimization of clutch size with respect to adult survival.
\end{abstract}

Received August 12, 1987. Accepted February 11, 1988

Studies of clutch size in birds have played an important role in the development of life-history theory in vertebrates (Lack, 1947, 1954, 1966; Stearns, 1976). Most work has attempted to explain differences in clutch size between species or among populations of the same species (Lack, 1966; Cody, 1971; Ricklefs, 1977; Winkler, 1985). Clutch size also varies between individuals within populations in a wide variety of species (Lack, 1966; Klomp, 1970; Murphy and Haukioja, 1986; Nur, 1986). Attempts to understand the causes of this variation are important, because they address the fundamental question of how variation in life-history traits evolved and is maintained.

Nur (1986) argued that there are three nonexclusive hypotheses to explain the maintenance of such variation. These are 1) individual optimization, whereby birds adjust their clutch size according to their ability to raise young, 2) trade-off of clutch size and future adult survival, such that the overall fitness of different clutch sizes is

\footnotetext{
1 Present address: Department of Biology, Queen's University, Kingston, ON K7L 3N6, Canada.
}

equal, and 3) oscillating directional selection, in which clutches of different sizes are favored in different years in a variable environment.

Recent work to evaluate these hypotheses has been largely experimental (cf. DeSteven, 1980; Hogstedt, 1980; Nur, 1984a, 1984b; Boyce and Perrins, 1987; but see Murphy [1986]). Long-term studies of unmanipulated bird populations can, however, provide important information in at least two ways. First, oscillating directional selection on clutch size can only be detected through long-term observations of natural populations of birds under a variety of environmental conditions (van Noordwijk et al., 1981; Boyce and Perrins, 1987). Second, both the trade-off and oscillating-selection hypotheses require the presence of genetic variation for clutch size. Long-term observations on marked individuals are required to collect the cross-generational data necessary to estimate the heritability of clutch size with standard quantitative-genetic techniques (Falconer, 1981). Demonstrating that clutch size is not heritable would exclude oscillating selection and negative genetic correlations between clutch size and 
TABle 1. Annual reproductive characteristics of $G$. fortis on Isla Daphne Major.

\begin{tabular}{lrrccc}
\hline \hline Year & $\begin{array}{c}\text { Rainfall } \\
(\mathrm{mm})\end{array}$ & Nests & $\begin{array}{c}\text { Mean clutch } \\
\text { size } \pm \text { SE }\end{array}$ & $\begin{array}{c}\text { \% eggs } \\
\text { fledged }\end{array}$ & $\begin{array}{c}\text { \% young } \\
\text { surviving }\end{array}$ \\
\hline 1976 & 135 & 190 & $3.16 \pm 0.05$ & 66.5 & 11.7 \\
1977 & 24 & 0 & - & - & - \\
1978 & 137 & 80 & $4.24 \pm 0.08$ & 67.2 & 65.0 \\
1979 & 69 & 89 & $3.02 \pm 0.08$ & 27.8 & 37.3 \\
1980 & 54 & 96 & $2.92 \pm 0.07$ & 6.0 & 0.0 \\
1981 & 80 & 102 & $3.75 \pm 0.07$ & 67.4 & 62.9 \\
1982 & 51 & 39 & $2.85 \pm 0.11$ & 11.7 & 0.0 \\
1983 & 1,359 & 406 & $4.11 \pm 0.04$ & 46.7 & 45.2 \\
1984 & 89 & 192 & $3.20 \pm 0.05$ & 64.1 & 42.5 \\
\hline
\end{tabular}

adult survival as explanations for clutchsize variation and would suggest that individual optimization and proximate environmental factors are more important.

Variation in clutch size has been shown to be heritable in all wild bird species studied, with $h^{2}$ values ranging from 0.23 to 0.50 (Perrins and Jones, 1974; Flux and Flux, 1981; van Noordwijk et al., 1981; Gustafsson, 1986; Findlay and Cooke, 1987). This has led some authors to base general explanations of clutch-size variation in birds on the assumption that such variation is largely genetic (Nur, 1986). Yet only four species have been studied, and there are theoretical reasons why, under certain conditions, a trait that is closely related to fitness (such as clutch size) should be under sustained directional selection and, hence, have a heritability close to zero (Falconer, 1981). In support of this argument, studies of litter size in mice have shown little additive genetic variance for this trait (Leamy, 1981). Thus, information from more bird species on both the heritability and pattern of selection on clutch size are needed to develop general explanations for variation in this life-history trait.

The purpose of this paper is to examine the causes of individual variation in clutch size in a population of Darwin's Medium Ground Finches (Geospiza fortis) on Isla Daphne Major, Galápagos. This work is the first detailed examination of clutch-size variation in a tropical passerine species living in an exceptionally variable environment (cf. Gibbs and Grant, 1987a, 1987b). Boag and Grant (1984a) and Price (1985) examined population-level effects of environmental conditions and density on clutchsize variation, but little attention was given to the causes of interindividual variation within and between years. Here, I consider whether clutch size is heritable in $G$. fortis and then examine selection acting on clutch size in different years over a nine-year period (1976-1984) using unusually complete measures of reproductive success (young fledged and surviving to the year following their birth). I then consider the importance of other proximate causes of variation in clutch size in an attempt to develop a broader understanding of the causes of variation in this life-history trait.

\section{MATERIALS AND METHODS}

Finch Populations. - The population of Darwin's Medium Ground Finches ( $G$. fortis) on Isla Daphne Major, Galápagos, has been studied intensively for the first 6-9 months of each year from 1976 until 1984 by P. T. Boag (1976-1978), T. D. Price (1979-1981), H. L. Gibbs (1982-1984), and B. R. Grant and P. R. Grant (Boag and Grant, 1984a; Price, 1985; Gibbs and Grant, $1987 a$ ). Daphne is a small island (<40 ha) situated in the middle of the Galápagos archipelago. A description of the geological and floristic characteristics is given in Boag and Grant (1984a). More than $95 \%$ of all $G$. fortis individuals have been banded with a metal band and a unique combination of three colored plastic bands since 1978. Approximately $30 \%$ of all adults were banded in 1976.

Breeding of the finches occurs in response to rain, which can fall during the months of December-June. The amount of annual rainfall varies considerably (Gibbs and Grant, 1987a). Females produced clutches in every year from 1976 to 1984 , except 1977. Clutch size (2-6 eggs) and breeding success, however, varied considerably between years (Table 1). I have used data from all years to estimate the heritability of clutch size. To evaluate selection on this trait, I concentrate on data from six successful years (1976, 1978, 1979, 1981, 1983, and 1984), when more than $10 \%$ of fledged young survived to the following year, allowing me to measure accurately the success of clutches of different sizes.

During each breeding season, all nests were marked, and all parents were identified. Nest contents were regularly checked 
to determine laying date, clutch size, hatching success, and fledging success. I am confident that more than $95 \%$ of all nests were found in each season from 1978 onwards, because repeated systematic searches of all potential nest sites, mostly Opuntia cactus bushes, were conducted and fledglings without bands were rarely seen. Occasionally, nests were found after the young hatched; these have been excluded from analyses of reproductive success that required complete nest histories. Nests with a clutch size of one were also excluded, because they probably represent incomplete clutches. No young fledged from clutches of this size. All young were banded and weighed eight days after hatching. Young birds that were alive in January of the year following the season of their birth were recorded and identified during repeated and standardized visual censuses and other observations (Boag and Grant, 1984a; Gibbs and Grant, 1987a).

Repeatability and Heritability Analyses. - The phenotypic variance in a trait $\left(V_{\mathrm{p}}\right)$ can be partitioned into genetic $\left(V_{\mathrm{g}}\right)$ and environmental $\left(V_{\mathrm{e}}\right)$ components. In turn, $V_{\mathrm{e}}$ is composed of both permanent and temporary environmental differences among individuals (Falconer, 1981). Controversy exists as to how to include temporary environmental effects on clutch size in quantitative analyses of this trait. For example, Perrins and Jones (1974) analyzed clutchsize data that had been corrected for effects due to age, habitat quality, and environmental differences between years. Van Noordwijk et al. (1981) argued, however, that this biased Perrins and Jones' analyses towards detecting heritability values that were unrealistically high and that the number of corrections performed was arbitrary. For my estimates of repeatability and heritability, I followed the approach of van Noordwijk et al. (1981) and used data from only the first clutch laid by a female in a given breeding season. I used two measures of clutch size in my analyses: normal clutchsize values (unadjusted for temporary environmental effects) and adjusted values, expressed as a deviation from the population mean of first clutches of all females in a given year. The mean clutch size of a female over two or more years was calculated as the average of either one of these mea- sures. An important assumption in making these corrections is that environmental differences between years affect the clutch size of each individual in the same way. Use of only the first clutch eliminates variance due to seasonal effects. No attempt was made to correct for other possible phenotypic differences among females.

Repeatabilities for corrected first clutch size were estimated as the intraclass correlation coefficient, based on variance components from a one-way ANOVA (Falconer, 1981; Lessels and Boag, 1987). All females observed to lay clutches in two or more years were used in the analyses. Heritabilities of first clutch size for females were estimated in two ways: 1) repeatability of clutch size within families of full sibs and 2) offspring-parent regressions of offspring on each parental value and of family means on parents. These analyses used clutch-size data combined across years, because samples were insufficient to carry out the analyses within most years. To check for possible paternal effects on clutch size (cf. van Noordwijk et al., 1981), I calculated repeatabilities and heritabilities from a comparison of the clutch sizes of females mated to particular males and females mated to the sons of those males.

Phenotypic Effects. - I also examined the effects of age, adult size, and habitat quality on clutch size. Age was scored as the number of years since birth. Size of an individual was estimated by six morphological traits (weight, wing length, tarsus length, bill length, bill depth, and bill width) and by first principal-component (PCI) scores extracted from a correlation matrix that included the six traits listed above. PCI is used as an index of overall body size, since all characters load positively on it and it explains a high proportion (approximately $65 \%$ ) of the overall variation among these traits (Boag and Grant, 1984b).

The heterogeneous distribution of vegetation on Daphne (Boag and Grant, 1984a) could potentially influence the availability of food to breeding females. Females usually spend a substantial amount of time foraging off their territories, which are usually less than 2,000 $\mathrm{m}^{2}$ in area (Price, 1984a, 1987). This mobility, combined with the small size of the island, suggests that habitat 
TABLE 2. Repeatabilities of unadjusted and adjusted first-clutch sizes between years. $R$ is the intraclass correlation coefficient.

\begin{tabular}{|c|c|c|c|c|}
\hline Character & $F$ ratio & d.f. & $P$ & $R$ \\
\hline \multicolumn{5}{|c|}{ Unadjusted clutch size } \\
\hline Females & 0.960 & 122,254 & 0.59 & 0.0 \\
\hline Males & 0.940 & 149,281 & 0.63 & 0.0 \\
\hline \multicolumn{5}{|c|}{ Adjusted clutch size } \\
\hline Females & 1.275 & 122,254 & 0.06 & 0.08 \\
\hline Males & 1.230 & 149,281 & 0.07 & 0.07 \\
\hline
\end{tabular}

effects, if present, are similar over large contiguous areas of the island. I therefore examined the effect of large-scale (10-20 ha) differences in habitat quality on clutch size in five years (1979-1981 and 1983-1984) for which vegetation samples were available (Gibbs and Grant, 1987a).

While breeding, these finches feed themselves and their young almost exclusively on arthropods, mainly caterpillars (Boag and Grant, 1984a; Price, 1985). Therefore, habitat quality was assumed to be related to caterpillar availability during the breeding season in different areas of the island. Caterpillar abundance was estimated by combining data on the percent coverage of different plant species in each of 20 arbitrarily located sectors with estimates of caterpillar numbers per square meter for each plant species (see Gibbs and Grant [1987a, 1987b] for details of the sampling methods used). Sectors were then ranked by total estimated caterpillar numbers and arbitrarily divided into groups of food-rich (ranks 1-10) and food-poor (ranks 11-20) sectors.

Selection on Clutch Size. - In each year, selection differentials for clutch size were calculated with two measures of success: the number of young fledged and the number of fledged young surviving to January of the next year. The selection differential is equal to the covariance between a trait and relative fitness and is equivalent to the shift in the mean value of a trait due to directional selection within a generation (Lande and Arnold, 1983).

Measuring selection across generations has the potential of confounding selection with inheritance (Arnold and Wade, 1984a, $1984 b$ ). Clutch size is a parental trait, whereas juvenile survival is a trait of off-
TABLE 3. Repeatabilities of unadjusted and adjusted first-clutch sizes within families of offspring. $R$ is the intraclass correlation coefficient.

\begin{tabular}{|c|c|c|c|c|}
\hline Character & $F$ ratio & $d . f$. & $P$ & $R$ \\
\hline \multicolumn{5}{|c|}{ Unadjusted clutch size } \\
\hline Females & 1.150 & 57,144 & 0.25 & 0.04 \\
\hline Males & 0.955 & 36,75 & 0.55 & 0.0 \\
\hline \multicolumn{5}{|c|}{ Adjusted clutch size } \\
\hline Females & 1.260 & 57,144 & 0.14 & 0.07 \\
\hline Males & 1.010 & 36,75 & 0.48 & 0.0 \\
\hline
\end{tabular}

spring. I assume that clutch size has a direct causal effect on the magnitude of both the number of young fledged and number surviving to the following year and that no parental traits exist that, through independent effects on both clutch size and offspring survival, lead to spurious associations between these life-history traits.

\section{RESUlts}

Repeatability and Heritability of Clutch Size.-Repeatabilities estimate the upper limit to the potential heritability of a trait, since consistent differences between individuals are due to both genetic and permanent environmental differences between individuals. Unadjusted clutch size was not detectably repeatable in females or males, while repeatabilities for first clutch size, adjusted for annual differences, are low and also nonsignificant in both females $(8 \%)$ and males $(7 \%)$ (Table 2 ). I also estimated repeatability of clutch size during the exceptionally long breeding season of 1982-1983, when individual females laid between three and ten clutches (Gibbs and Grant, 1987b). After adjusting for monthly differences in clutch size, I found the within-year repeatability of clutch size among females (7\%) to be significant $(P=0.04)$ and similar in magnitude to the between-year figure for adjusted clutch size.

Low repeatabilities for clutch size suggest that heritability of this trait should be no greater than 0.08 . Sib-sib comparisons and parent-offspring regressions confirm this (Tables 3, 4). The repeatability of first clutch size is not detectably different from zero among families of either female or male offspring for either unadjusted or adjusted clutch sizes (Table 3). Parent-offspring 
TABLE 4. Slopes of parent-offspring regressions for unadjusted and adjusted first-clutch sizes.

\begin{tabular}{lrrrrr}
\hline \hline \multicolumn{1}{c}{ Character } & \multicolumn{2}{c}{ Mother-daughter } & & \multicolumn{2}{c}{ Father-son } \\
\cline { 2 - 3 } \cline { 5 - 6 } & $N$ & $b \pm \mathrm{SE}$ & & \multicolumn{1}{c}{$b \pm \mathrm{SE}$} \\
\hline Unadjusted clutch size & & & & & \\
$\quad$ Mean of parent versus mean of each offspring & 231 & $-0.10 \pm 0.08$ & & 162 & $-0.04 \pm 0.12$ \\
$\quad$ Mean of parent versus family mean & 79 & $-0.09 \pm 0.14$ & & 81 & $-0.11 \pm 0.14$ \\
$\quad \begin{array}{l}\text { Adjusted clutch size } \\
\quad \text { Mean of parent versus mean of each offspring }\end{array}$ & 231 & $-0.17 \pm 0.07^{*}$ & & 162 & $0.08 \pm 0.12$ \\
$\quad$ Mean of parent versus family mean & 79 & $-0.17 \pm 0.12$ & & 81 & $-0.03 \pm 0.14$ \\
\hline$* P<0.05$ & & & & & \\
\hline
\end{tabular}

regressions give more direct estimates of the heritabilities of traits, because they do not include the effects of common environments experienced by sibs. For unadjusted first clutches, slopes for all mother-daughter and father-son regressions are small, nonsignificant, and negative in sign (Table 4). For adjusted clutches, slopes of both fatherson regressions are small and nonsignificant while slopes of mother-daughter regressions are larger, negative, and, in one case, significantly different from zero (Table 4). Correcting for small age effects (see below) does not alter these results. Negative slopes of parent-offspring regressions suggest that the additive genetic variance for a trait is close to zero (cf. Leamy, 1981) and that negative maternal effects on values of daughters' traits are present (Falconer, 1960, 1965).

In two years (1983 and 1984), there were sufficient data to estimate within-family repeatabilities for sisters and mother-daughter regressions for adjusted clutch sizes. These values are similar to the overall figures: repeatability values are $0 \%(1983, N=$ 44 families) and $8 \%(1984, N=10$; both $P>0.05)$, while slopes of the regressions were $-0.25 \pm 0.12 \mathrm{SE}(1983, N=139)$ and $0.10 \pm 0.10(1984, N=138)$.
Due to gene $\times$ environment interactions, detected heritabilities and repeatabilities for clutch size might be dependent on the habitat in which parents and offspring bred. I examined this possibility by calculating repeatabilities and parent-offspring regressions for females and mother-daughter pairs that bred exclusively in either good or poor habitats in $1979,1981,1983$, and 1984. In no case were repeatabilities or regressions significantly different from zero, and values for particular analyses are similar between habitats (Table 5).

Overall, these results indicate that there is little or no additive genetic variance for clutch size in this population and that most $(>90 \%)$ of the intrapopulation variation in clutch size is due to transient environmental effects on females. Furthermore, negative maternal effects on clutch size may be present.

Phenotypic Effects. - The lack of a heritable component for clutch-size variation suggests that most variation is due to proximate environmental or phenotypic factors. I therefore examined the relationship between clutch size and three possible factors (adult size, habitat quality, and female age). Univariate correlations between male and

TABLE 5. Repeatability $(R)$ mother-daughter regression analyses of adjusted clutch size in different habitats. Data are from $1979,1981,1983$, and 1984 only.

\begin{tabular}{llll}
\hline \hline \multicolumn{1}{c}{ Analysis } & Statistic & Good habitat & Poor habitat \\
\hline Repeatabilities within females & $R$ & 0.0 & 0.10 \\
& $F(d . f)$ & $0.785(31,46)$ & $1.29(31,55)$ \\
& $P$ & 0.76 & 0.20 \\
Repeatabilities within families of female offspring & $R$ & 0.08 & 0.07 \\
& $F(d . f)$ & $1.28(40,88)$ & $1.25(80,165)$ \\
Regressions of mean of daughter on mean of mother & $P$ & 0.17 & 0.12 \\
& $b \pm \mathrm{SE}$ & $0.03 \pm 0.12$ & $0.08 \pm 0.17$ \\
\hline
\end{tabular}


TABlE 6. Results of two-way ANOVAs within years, testing for habitat and age effects on first clutch size for 1979-1981, 1983, and 1984. Abbreviations for effects are $\mathrm{H}=$ habitat type, $\mathrm{A}=$ age in years, $\mathrm{HA}=$ interaction, and $\mathrm{E}=$ error.

\begin{tabular}{clrrccc}
\hline \hline Year & Factor & \multicolumn{1}{c}{ SS } & d.f. & MS & $F$ & $P$ \\
\hline 1979 & H & 0.40 & 1 & 0.40 & 0.58 & 0.49 \\
& A & 1.74 & 1 & 1.74 & 2.55 & 0.12 \\
& HA & 0.21 & 1 & 0.21 & 0.30 & 0.59 \\
& E & 28.08 & 41 & 0.68 & & \\
1980 & H & 0.51 & 1 & 0.51 & 0.92 & 0.33 \\
& A & 2.03 & 1 & 2.03 & 3.75 & 0.06 \\
& HA & 0.03 & 1 & 0.03 & 0.05 & 0.82 \\
& E & 27.57 & 51 & 0.54 & & \\
1981 & H & 0.47 & 1 & 0.47 & 0.65 & 0.42 \\
& A & 0.37 & 1 & 0.37 & 0.52 & 0.48 \\
& HA & 0.01 & 1 & 0.01 & 0.01 & 0.92 \\
& E & 37.11 & 51 & 0.73 & & \\
1983 & H & 0.15 & 1 & 0.15 & 0.24 & 0.62 \\
& A & 2.04 & 2 & 1.02 & 1.66 & 0.20 \\
& HA & 1.69 & 2 & 0.85 & 1.38 & 0.26 \\
& E & 27.62 & 45 & 0.61 & & \\
1984 & H & 0.06 & 1 & 0.06 & 0.13 & 0.72 \\
& A & 5.17 & 2 & 2.59 & 5.29 & 0.01 \\
& HA & 0.25 & 2 & 0.13 & 0.26 & 0.77 \\
& E & 62.51 & 128 & 0.49 & & \\
\hline
\end{tabular}

female morphological traits (weight, wing length, tarsus length, bill length, bill depth, and bill width) and adjusted first-clutch size, averaged over all breeding seasons, were small and nonsignificant (females: range of $r$ values $=-0.02-0.10, N=149-177$, all $P>0.05$; males: $r=-0.03--0.11, N=$ 167-210; all $P>0.05$ ). There was also no significant correlation between mean clutch size and PCI scores (females: $r=0.03, N=$ 149; $P>0.05$; males: $r=-0.02 ; N=167$; $P>0.05)$ or evidence of stabilizing selection, since the quadratic terms $\left([\mathrm{PCI}]^{2}\right)$ in polynomial regressions of PCI on mean clutch size were not significant for females $(P=0.95)$ or males $(P=0.75)$. Analyses within breeding seasons show a similar pattern: in females, only four of 56 correlations of clutch size with morphology were significant, each involving a different character; while in males, only one of 56 comparisons was significant. Overall, variation in adult body size does not appear to be related to variation in clutch size (see also Price [1984b]).

I used a two-way analysis of variance to assess the effects of female age and habitat type on unadjusted clutch size in different

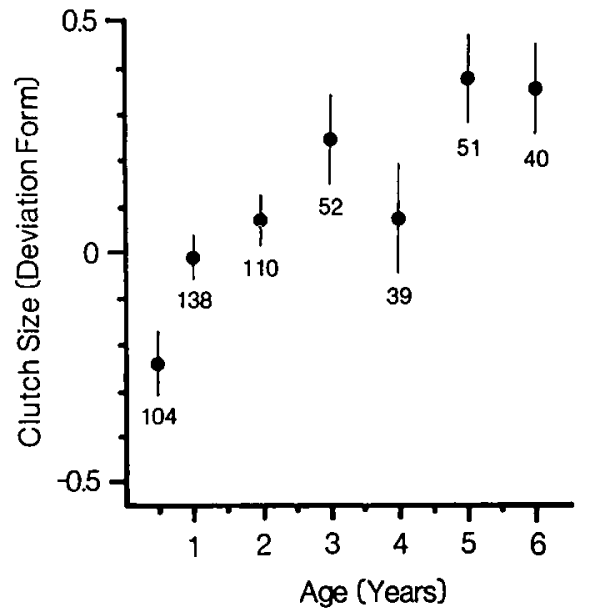

Fig. 1. Relationship between female age and first clutch size, adjusted for annual differences. The equation for the best-fit regression line is: $Y=0.09 X-$ 0.16, d.f. $=533, P<0.001, R^{2}=0.06$.

breeding seasons. In no year was there a significant effect of habitat type on clutch size, but age effects were present in 1980 $(P=0.06)$ and $1984(P=0.01)$ (Table 6). No interaction between main effects (age and habitat) was observed in any year.

As suggested above, female age was positively correlated $(P<0.05)$ with adjusted clutch size for females six months to six years old (Fig. 1). The slope of the best-fit regression line $(0.09)$ is low, however, indicating that the per year increase in clutch size is quite small. Data for older females (7-10 years old) were excluded from the analysis, because sample sizes were much smaller ( $N \leq 20$ per age class) relative to the younger cohorts. The mean clutch size for all older birds combined $(0.15 \pm 0.14$ $\mathrm{SE}, N=49$ ) suggests that there is an asymptotic relationship between clutch size and age. Including the older birds in the regression reduces the slope to 0.07 . There is no evidence for a decline in clutch size with age since the second-order term ([clutch size $]^{2}$ ) is not significant in polynomial regression analyses for younger birds only ( $0.5-6$ years) or for all females combined.

The mechanism for the small age-related increase in clutch size is unknown. Clutch size is not related to the duration of the pairbond between two breeding seasons (cf. Rowley, 1983), since there is no difference 

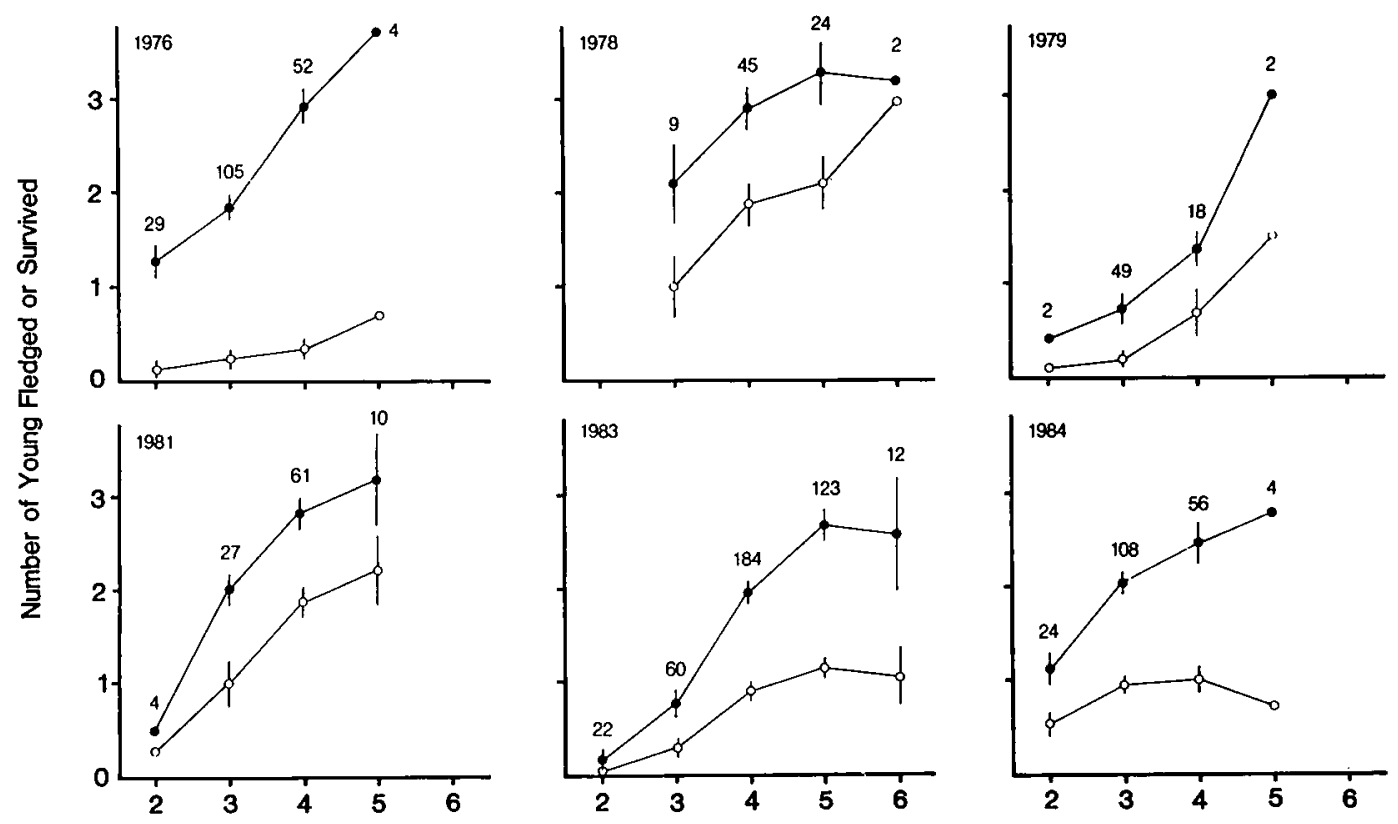

Chutch Size

FIG. 2. Relationship between clutch size and both fledging success and survival of young for all years in which successful breeding occurred. Solid circles are mean values for fledging success \pm 1 SE; open circles are mean values for young surviving to the following year \pm 1 SE. Standard errors were only calculated for cases in which $N>8$. Sample sizes are given above each mean value.

between the mean clutch size of females with the same mate from the previous breeding season and that of females with a different mate when data are pooled for the 1979 to 1984 breeding seasons. Females with the same mate had a mean clutch size (expressed as a deviation from the annual mean) of $-0.13 \pm 1.20 \mathrm{SD}(N=114)$, while the mean for females with different mates was $0.08 \pm 1.04(N=177 ; t=1.45, P=0.15)$.

Selection on Clutch Size. - Figure 2 shows the relationships between clutch size and both fledging success and young surviving for the six years in which successful breeding occurred. All clutches laid by females in a given year are included, except for 1983, when clutches laid by females born earlier in the year were excluded because they bred at an unusually early age and experienced strong age-dependent effects on their breeding success (Gibbs et al., 1984). In most years, there is a positive relationship between clutch size and both measures of reproductive success, although standard errors of sequential clutch sizes overlap in some cases. Differences in fledging success are more pronounced than differences in young surviving. In some instances, however, the positive relationship between clutch size and success levels off at higher clutch sizes (fledging success in 1978; fledging success and young surviving in 1983). There was also little difference in the number of young surviving between clutch sizes in 1984. The success of clutches of different sizes for data combined over all six years shows a leveling off of success at the highest clutch sizes (Fig. 3 ); this result is dominated by the large number of nests from a single year (1983; $38 \%$ of the total).

Selection differentials, which provide a quantitative measure of the directional selection on clutch size, are all positive and, in most cases (10 out of 12), statistically significant (Table 7). To check for possible stabilizing selection on clutch size, I tested for the significance of a quadratic term ([clutch size] ${ }^{2}$ ) in polynomial regressions of clutch size on both measures of success (cf. Nur, 1984a). In no case was this secondorder term significant $(P=0.09-0.88)$. Selection differentials were also similar for first 


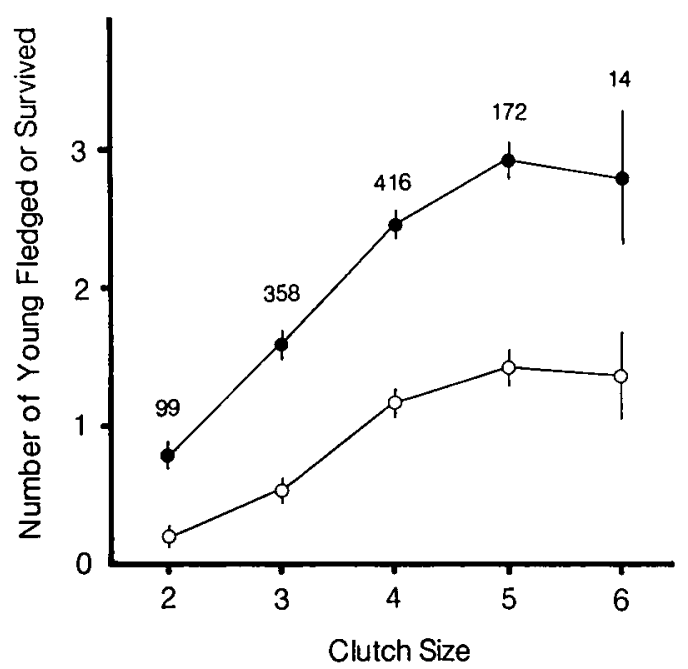

FIG. 3. Relationship between clutch size and both fledging success and survival of young for all six successful years combined. Details of figure contents are the same as for Figure 2.

clutches only and for nests in different habitats (all first clutches: $S_{\text {[fledged young] }}=0.54$, $S_{\text {[surviving young] }}=0.38, N=472$, both $P \leq$ 0.01 ; good habitat: $S_{\text {[fledged young] }}=0.24$, $S_{\text {[surviving young] }}=0.30, N=366$; poor habitat: $S_{\text {[fledged young] }}=0.30, S_{\text {[surviving young] }}=0.29$, $N=364$, all $P \leq 0.05$ ). Finally, clutches fledging one or more young or with one or more young surviving were significantly larger $(P \leq 0.05)$ than clutches with no young fledging or surviving, except for the comparisons involving fledged young in 1978 and surviving young in 1984. Thus, in general, larger clutches produce more surviving offspring, although in some years there is no difference in the number of young produced. Smaller clutches were never more successful than larger ones (cf. van Noordwijk et al., 1981), and there was no evidence of stabilizing selection.

Seasonal variation in reproductive success could confound the results of the selection analyses. For example, fledging success has been found to decline with laying date in several species (Perrins, 1979; Boyce and Perrins, 1987), and so large clutches could be more successful simply because they were laid earlier in a season. I examined this possibility and found significant negative correlations between clutch size and the date on which the first egg was laid in
TABle 7. Selection differentials for Geospiza fortis clutch size in all years in which more than $10 \%$ of fledged young survived to the following year. $S$ is the selection differential, and $N$ is the number of clutches.

\begin{tabular}{lrll}
\hline \hline Year & \multicolumn{1}{c}{$N$} & $S_{\text {[ledged young] }}$ & $S_{\text {[surviving young] }}$ \\
\hline 1976 & 190 & $0.17^{*}$ & $0.26^{*}$ \\
1978 & 80 & 0.07 & $0.12^{*}$ \\
1979 & 89 & $0.37^{* *}$ & $0.60^{* *}$ \\
1981 & 102 & $0.15^{* *}$ & $0.20^{* *}$ \\
1983 & 406 & $0.33^{* *}$ & $0.32^{* *}$ \\
1984 & 192 & $0.13^{*}$ & 0.06 \\
Combined & 1,059 & $0.25^{* *}$ & $0.38^{* *}$ \\
\hline
\end{tabular}

$* P \leq 0.05 ; * * P \leq 0.01$.

four of seven years $(1976,1981,1983$, and 1984). The number of young fledged per egg was negatively correlated with first egg date in two years (1983 and 1984), and young per egg surviving to January was negatively correlated with first egg date in all four years. I attempted to remove the effect of season on reproductive success by recalculating the selection differentials on clutch size, using the residuals of two separate regressions: a) the number of young fledged (1983 and 1984) and b) the number of young surviving to January (1976, 1981, 1983, and 1984), on first egg date for each nest in each respective year. In all cases, the selection differentials remained positive, and there was no change in the significance of individual values. Thus, seasonal effects alone do not account for the consistently strong directional selection on clutch size in this population.

Chick Weights. --Previous work with other birds has shown that chicks fledging from large clutches are lighter; hence, they survive less well during the first 3-6 months of life than those from smaller clutches (Perrins, 1979). With regard to $G$. fortis, in four of five breeding seasons in which sample sizes were adequate $(N>10$ nests) individual chick weights were not significantly different among clutches of varying size (ANOVA, $P>0.05$; Table 8). In 1984, chick weight declined with increasing clutch size $(P<0.001)$. Similar patterns are found in different habitats within years. In addition, chick weight was not correlated with fledgling survival to January of the following year in most years. Price and Grant (1984 table 5) found no difference between the weights of chicks that survived and those of chicks 
TABLE 8. Mean chick weight $(g \pm S D)$ in relation to clutch size in different years. The numbers of nests for given clutch size are given in parentheses. $P$ values given are from one-way ANOVAs.

\begin{tabular}{|c|c|c|c|c|c|c|}
\hline \multirow[b]{2}{*}{ Year } & \multicolumn{5}{|c|}{ Clutch size } & \multirow[b]{2}{*}{$P$} \\
\hline & 2 & 3 & 4 & 5 & 6 & \\
\hline 1976 & $\begin{array}{c}12.9 \pm 2.9 \\
(16)\end{array}$ & $\begin{array}{c}12.9 \pm 2.2 \\
(76)\end{array}$ & $\begin{array}{c}12.4 \pm 2.1 \\
(45)\end{array}$ & $13.4 \pm 0.75$ & - & 0.72 \\
\hline 1978 & - & $12.9 \pm \frac{ \pm}{(6)} 1.3$ & $13.0 \pm \frac{1.8}{(35)}$ & $\begin{array}{c}13.0 \pm 1.3 \\
(20)\end{array}$ & $14.0 \pm 0.87$ & 0.85 \\
\hline 1981 & - & $12.1 \pm 2.3$ & $\begin{array}{c}11.6 \pm 2.6 \\
(52)\end{array}$ & $12.3 \pm 2.5$ & - & 0.62 \\
\hline 1983 & $12.3 \pm \underset{(2)}{ \pm} 2.5$ & $\begin{array}{c}13.3 \pm 3.1 \\
(15)\end{array}$ & $\begin{array}{c}14.2 \pm 2.2 \\
(129)\end{array}$ & $\begin{array}{c}13.9 \pm 2.2 \\
(95)\end{array}$ & $13.5 \pm \frac{2.4}{(8)}$ & 0.36 \\
\hline 1984 & $14.2 \pm 2.0$ & $13.7 \pm 1.5$ & $12.6 \pm \frac{1.8}{(43)}$ & $14.0 \pm 2.5$ & - & 0.002 \\
\hline
\end{tabular}

that disappeared in four breeding seasons $(1976,1978,1979$, and 1981). Additionally, no difference was present between survivors and nonsurvivors in 1983 (weights of chicks that survived: mean $=13.9 \mathrm{~g}, \mathrm{SD}=5.8 \mathrm{~g}$, $N=361$; weights of chicks that died: mean = $14.1 \mathrm{~g}$; $\mathrm{SD}=7.3 \mathrm{~g}, N=439$; Mann-Whitney $U$ test, $P=0.10$ ) while heavier offspring survived better in 1984 (weights of chicks that survived: mean $=14.1 \mathrm{~g}, \mathrm{SD}=4.7 \mathrm{~g}$, $N=181$; weights of chicks that died: mean $=13.4 \mathrm{~g}, \mathrm{SD}=6.7 \mathrm{~g}, N=236$; MannWhitney $U$ test, $P<0.05$ ). Thus, the general mechanism leading to selection against large clutch size in other birds appears to be lacking in G. fortis.

\section{Discussion}

The most significant result of this study is that, given sample sizes comparable with those in other studies, there is no evidence for heritable variation in clutch size in $G$. fortis. My results stand in marked contrast to studies of other birds, which have shown significant additive genetic variation for this trait (for review, see Hailman [1986], and Murphy and Haukioja [1986]). This implies that the pattern of selection on life-history variation in these finches is different from other birds and that proximate determinants of clutch size may be unusually important in this species.

The observed pattern of selection on clutch size suggests why heritability is lacking: sustained directional selection has reduced the additive genetic variance for this trait to low levels, possibly zero. These results may pro- vide a predicted but rarely observed natural example of an important corollary of Fisher's Fundamental Theorem, namely that characters closely related to fitness should have heritabilites near zero (Robertson, 1955; Istock, 1978; Falconer, 1981; Gustafsson, 1986).

I emphasize that these conclusions are tentative, because directional selection was not observed in one year (1984), and in another year (1983) there was little difference in fitness between the two largest clutch sizes. However, I suggest that, because a consistent pattern of selection for large clutch size was observed under a wide range of breeding conditions, the currently observed small differences in success between clutch sizes have been evolutionarily significant over longer periods of time in the past.

Both direct and indirect evidence from other studies confirms that strong directional selection can reduce variation in lifehistory traits. For example, Istock et al. (1976) reported that artificial selection for fast development in pitcher plant mosquitos (Wyeomyia smithii) reduced the heritability of this trait from 0.33 to effectively zero in 15 generations or less. Nordskog (1977) argued that sustained directional selection in the past is responsible for the lack of increase in egg production in present-day breeds of domestic chickens. A similar process may have led to low heritability of litter size in some domestic breeds of mice and pigs (Falconer, 1981).

Alternatively, Bull (1987) has argued that the genetic and environmental components 
of phenotypic variation in a quantitative trait may evolve independently of each other. Thus, $G$. fortis may show no evidence for heritable variation in clutch size because, while absolute levels of additive variation are similar to those in other species, the environmental component, for unknown reasons, is much larger and swamps out the contribution of $V_{\mathrm{g}}$ to $V_{\mathrm{p}}$. If this were the case, however, then overall phenotypic variation in clutch size in $G$. fortis should be considerably larger than that in species showing heritable variation in this trait. This does appear to be true: the coefficient of variation for mean annual clutch size in $G$. fortis ranges from $17 \%$ to $25 \%$ (Table 1 ), which is similar to values for Great Tits (24\%; calculated from data in Boyce and Perrins [1987]) and many other birds (Hogstedt, 1980).

The negative relationship between the clutch size of mothers and their daughters suggests a negative maternal effect on the clutch size of offspring in these birds. This phenomenon occurs in lab mice (Falconer, 1960, 1965; Eisen, 1970) and operates through a negative effect of mother's litter size on the adult weight of a daughter, followed by a positive effect of daughter's weight on her litter size. This particular mechanism probably does not apply to these birds, because there is no relationship between adult body size and clutch size (Price, $1984 b$; this study), and there is a strong positive relationship between the body size of offspring and their parents (Boag, 1983). For example, body weight has a heritability of between 0.81 and 0.91 , depending on the type of parent-offspring regression performed (Boag, 1983). At present, it is not clear what other mechanism could be responsible for the observed maternal effects in these birds.

Several factors may confound estimates of heritabilities based on data from nonexperimental field studies (van Noordwijk et al., 1981; Hailman, 1986). Most, however, act to inflate the amount of the total phenotypic variation that is mistakenly attributed to additive genetic effects. For example, estimated heritabilites could be inflated by nonadditive genetic factors such as maternal effects, assortative mating, and gene $x$ environment correlations. This study has a different problem: low heritabilites are only detectable with very large sample sizes. In addition, negative maternal effects can mask the presence of small amounts of additive genetic variation. For example, Falconer (1965) estimated the heritability of litter size in mice to be -0.56 and argued that the negative value was due to maternal effects. Eisen (1970), after accounting for maternal effects by manipulating litter sizes, calculated the heritability of the same trait to be 0.14 . Clearly, I cannot exclude the possibility that there are low, undetected levels of additive genetic variation for clutch size present in this population. However, the low repeatability of clutch size estimated from within-individual and family analyses suggests that such levels are still substantially lower than those observed in other birds.

The lack of heritable variation in clutch size suggests that long-term trade-offs between survival and fecundity may be unimportant in Darwin's Medium Ground Finches, possibly because the evolutionary processes that determine variation in each life-history trait are largely independent. As Price (1984b) and Price and Grant (1984) have emphasized, morphological traits, which determine most of the nonrandom variation in individual survival in these birds, are largely uncorrelated with measures of fecundity. Thus, because the traits responsible for variation in one life-history trait (survival) do not influence variation in another (fecundity), negative correlations between the traits have not evolved.

There is more direct evidence that a cost to reproduction, required by a trade-off model, may be unimportant in these birds, at least within the range of clutch sizes currently observed. Gibbs and Grant (1987a, $1987 \mathrm{~b}$ ) showed that variations in different measures of reproductive output within a season are not correlated with the probability of surviving to the following year. Lifetime survival also does not appear to be related to variation in mean clutch size among the cohort of females born in 1978 (see Gibbs and Grant, 1987b). The correlation between mean first clutch size and number of years alive was small and nonsignificant ( $r=-0.07, N=49$ females, $P>$ $0.05)$. It is important to emphasize that sur- 
vival costs may be present but difficult to detect using purely phenotypic measures of reproductive effort (Reznick, 1985). Results based on correlations must be confirmed with experiments in which reproductive output is manipulated and subsequent effects on individual survival are recorded.

Reproductive costs may, nonetheless, set the upper limit to clutch size in this population. The maximum observed clutch sizes (5-6) may represent a threshold, in that clutches of seven or greater entail disproportionately high survival costs, and females avoid this fixed cost by never exceeding the threshold. Thus the low genetic component to clutch size may result from long-term selection acting to fix genetic variation for clutch size at this threshold value. I suggest, therefore, that current variation in clutch size is caused by individual and environmental constraints (see below), which, in all except the most favorable conditions, prevent females from laying the maximum clutch sizes possible.

The difference in heritability of clutch size between $G$. fortis and other birds could also be related to differences in the patterns of selection on clutch size. Stabilizing selection on a quantitative trait like clutch size, combined with input from mutation, could act to preserve genetic variation in such a trait (Lande, 1976; Grant and Price, 1981). Selection against large clutches in some birds occurs because of a negative relationship between clutch size and chick weight (Lack, 1966). This causes reduced per capita recruitment from large clutches, because chick weight has a positive effect on juvenile survival (Perrins, 1979). The lack of stabilizing selection on clutch size in $G$. fortis may occur because there is no consistent relationship between chick weight and clutch size or between chick weight and subsequent survival. Chick weight and clutch size are independent in finches because, while chick weight is heritable (Price and Grant, 1985), there is no association between adult size and clutch size. Genetic variation in chick size may therefore mask any proximate effects of clutch size on chick weight. Reduced recruitment per egg from large clutches may, in fact, be uncommon in birds, since a large number of studies have shown no relationship between clutch size and chick weight
(Haukioja, 1970; Hussel, 1972; Murphy, 1978; Hogstedt, 1980; Loman, 1980; Slagsvold, 1982) or no effect of chick weight on subsequent survival (Ross and McLaren, 1980). Thus, sustained directional selection on clutch size in birds may commonly occur, resulting in more species showing low heritabilities for clutch size than has been previously suspected.

Clutch-size variation in most birds is probably influenced to varying degrees by several broadly different ecological and evolutionary mechanisms (Nur, 1986). The present study excludes mechanisms requiring heritable variation as significant causes of clutch-size variation in $G$. fortis. Rather, it suggests that the reproductive response of individual females to unidentified proximate environmental and physiological factors is of greater importance and that these factor(s), which determine over $90 \%$ of variation in clutch size of individual females, vary from season to season. Possible factors include female condition as determined by nonbreeding season conditions (Jones and Ward, 1976), amount of male courtship feeding (Royama, 1966), annual variation in territory quality, variation in nest size (Slagsvold, 1982), and parasite loads (Brown and Brown, 1986). I have no information on the relative importance of these factors, although the positive relationship between caterpillar abundance and overall mean clutch size within and between years (Price, 1985; Gibbs and Grant, 1987b) suggests that food availability to a female during the period preceding laying might be crucial. The unpredictability of rainfall and, hence, breeding resources following the initial decision to breed (Boag and Grant, 1984a; Price, 1985) may also result in a large environmental component to clutch size. Further work on variation in clutch size in these birds should concentrate on assessing the relative importance of these factors.

\section{ACKNOWLEDGMENTS}

I thank P. Boag, S. Dobson, J. Fry, P. Myers, R. Payne, T. Price, P. Smouse, and especially P. Grant for comments on the manuscript, J. Gibbs, S. Latta, and J. Weiland for help in the field, and P. Boag and $T$. Price for the use of their data. This work was carried out with the permission of the 
Dirección General de Desarrollo, Quito, Ecuador, and with the help of the Servicio Parque Nacional Galápagos, and the Charles Darwin Research Station. It was supported by NSERC (Canada) and NSF (U.S.A.) grants to P. R. Grant. I was supported by an NSERC (Canada) Postgraduate Scholarship, Block Grants from the Department of Biology, University of Michigan, and a Hinsdale Scholarship from the Museum of Zoology, University of Michigan.

\section{Literature Cited}

ARnold, S., AND M. J. WADE. 1984a. On the measurement of natural and sexual selection: Theory. Evolution 38:709-719.

- $1984 b$. On the measurement of natural and sexual selection: Applications. Evolution 38:720734.

BoAg, P. T. 1983. The heritability of external morphology in Darwin's Ground Finches (Geospiza) on Isla Daphne Major, Galápagos. Evolution 37:877894.

Boag, P. T., and P. R. Grant. 1984a. Darwin's Finches (Geospiza) on Isla Daphne Major, Galápagos: Breeding and feeding ecology in a climatically variable environment. Ecol. Monogr. 54:463489.

- 1984b. The classical case of character release: Darwin's Finches (Geospiza) on Isla Daphne Major, Galápagos. Biol. J. Linn. Soc. 22:243-287.

Boyce, M., AND C. M. Perrins. 1987. Optimizing Great Tit clutch size in a fluctuating environment. Ecology 68:142-153.

Brown, C. R., AND M. B. BRown. 1986. Ectoparasitism as a cost of coloniality in Cliff Swallows ( $\mathrm{Hi}$ rundo pyrrhonota). Ecology 67:1206-1218.

BuLL, J. 1987. Evolution of phenotypic variance. Evolution 41:303-315.

CoDy, M. 1971 Ecological aspects of reproduction, pp. 46I-512. In D. S. Farner and J. R. King (eds.), Avian Biology, Vol. 1, Academic Press, N.Y.

DeSteven, D. 1980. Clutch size, breeding success, and parental survival in the Tree Swallow (Iridoprocne bicolor). Evolution 34:278-291.

EISEN, E. J. 1970. Maternal effects on litter size in mice. Can. J. Genet. Cytol. 12:209-216.

FALCONER, D. 1960. The genetics of litter size in mice. J. Cell. Comp. Physiol. 56(suppl. 1):153-167.

- 1965. Maternal effects and selection response. Proc. XI Internat. Cong. Genet. 3:763-774.

—_. 1981. Introduction to Quantitative Genetics, 2nd Ed. Longman, London, U.K.

FINDLAY, C. S., AND F. COOKE. 1987. Repeatability and heritability of clutch size in Lesser Snow Geese. Evolution 41:453.

Fuux, J. E. C., AND M. M. Flux. 1981. Artificial selection and gene flow in wild Starlings (Sturnus vulgaris). Naturwissenschaften 69:96-97.

GibBs, H. L., AND P. R. Grant. 1987a. Adult survival in Darwin's Ground Finch (Geospiza) populations in a variable environment. J. Anim. Ecol. 56:797-813.
- 1987b. Ecological consequences of an exceptionally strong El Niño event on Darwin's Finches. Ecology 68:1735-1746.

GibBs, H. L., P. R. Grant, and J. Weiland. 1984. Breeding of Darwin's Finches at an unusually early age in a El Niño year. Auk 101:872-874.

Grant, P. R., AND T. D. Price. 1981. Population variation in continuously varying traits as an ecological genetics problem. Amer. Zool. 21:795-811.

Gustafsson, L. 1986. Lifetime reproductive success and heritability: Empirical support for Fischer's fundamental theorem. Amer. Natur. 128:761-764.

HAILMAN, J. P. 1986. The heritability concept applied to wild birds. Curr. Ornithol. 4:71-95.

Haukioja, E. 1970. Clutch size of the Reed Bunting (Emberiza schoeniclus). Orn. Fenn. 47:101-135.

HoGSTEDT, G. 1980. Evolution of clutch size in birds: Adaptive variation in relation to territory quality. Science 210:1148-1150.

Hussel, D. J. T. 1972. Factors affecting clutch size in arctic passerines. Ecol. Monogr. 42:317-364.

Istock, C. A. 1978. Fitness variation in a natural population, pp. 171-190. In H. Dingle (ed.), Evolution of Insect Migration and Diapause. SpringerVerlag, N.Y.

Istock, C. A., J. Zisfein, AND K. J. VAvra. 1976. Ecology and evolution of the pitcher-plant mosquito: 2 . The substructure of fitness. Evolution 30 : 535-547.

JONES, P. J., AND P. WARD. 1976. The level of reserve protein as the proximate factor controlling the timing of breeding in the Red-billed Quelea (Quelea quelea). Ibis $118: 547-574$

KLOMP, H. 1970. The determination of clutch size: A review. Ardea 98:1-124.

LACK, D. 1947. The significance of clutch size. Ibis 89:302-352.

- 1954. The Natural Regulation of Animal Numbers. Clarendon, Oxford, U.K.

- 1966. Population Studies of Birds. Clarendon, Oxford, U.K.

LANDE, R. 1976. The maintenance of genetic variability by mutation in a polygenic character with linked loci. Genet. Res. 26:221-235.

LANDE, R., AND S. ARNOLD. 1983. The measurement of selection on correlated characters. Evolution 37: 1210-1226.

LEAMY, L. 1981. The effect of litter size on fertility in Peromyscus leucopus. J. Mammal. 62:692-697.

LESSELS, C. M., AND P. T. BOAG. 1987. Unrepeatable repeatabilities: A common mistake. Auk 104:116121.

LOMAN, J. 1980. Brood size optimization and adaptation among Hooded Crows (Corvus corone). Ibis 122:494-500.

MuRPHY, E. C. 1978. Seasonal variation in reproductive output of House Sparrows: The determination of clutch size. Ecology 59:1189-1199.

MurPhy, E. C., AND E. HaukioJa. 1986. Clutch size in nidicolous birds. Curr. Ornithol. 4:141-180.

MurPHy, M. T. 1986. Temporal components of reproductive success in Eastern Kingbirds (Tyrannus tyrannus). Ecology 67:1483-1492.

NORDSKOG, A. W. 1977. Success and failure of quantitative genetic theory in poultry, pp. 569-586. In E. Pollack, O. Kempthorne, and T. B. Bailey, Jr. 
(eds.), Proceedings of the International Congress of Quantitative Genetics. Iowa State Univ. Press, Ames.

NUR, N. 1984a. The consequences of brood size for breeding blue tits I. Adult survival, weight change and the cost of reproduction. J. Anim. Ecol. 53: $479-496$.

. 1984b. The consequences of brood size for breeding blue tits II. Nestling weight, offspring survival and optimal brood size. J. Anim. Ecol. 53: 497-517.

1986. Alternative reproductive tactics in birds: Individual variation in clutch size, pp. 49-77. In P. P. G. Bateson and P. H. Klopfer (eds.), Perspectives in Ethology, Vol. 7. Plenum, N.Y.

Perrins, C. M. 1979. British Tits. Collins, London, U.K.

Perrins, C. M., ANd P. J. Jones. 1974. The inheritance of clutch size in the Great Tit (Parus major L.). Condor 76:225-229.

Price, T. D. 1984a. Sexual selection and body size, plumage and territory variables in a population of Darwin's Finches. Evolution 38:327-341.

- 1984b. The evolution of sexual size dimorphism in Darwin's Finches. Amer. Natur. 123:500513.

- 1985. Reproductive responses to varying food supply in a population of Darwin's Finches: Clutch size, growth rates and hatching synchrony. Oecologia 66:411-416.

- 1987. Diet variation in a population of Darwin's Finches. Ecology 68:1015-1028.

Price, T. D., AND P. R. Grant. 1984. Life history traits and natural selection for small body size in a population of Darwin's Finches. Evolution 38:483494.
1985. The evolution of ontogeny in Darwin's Finches: A quantitative genetics approach. Amer. Natur. 125:169-188.

REZNICK, D. 1985. Costs of reproduction: An evaluation of the evidence. Oikos 44:257-267.

RICKLEFS, R. E. 1977. On the evolution of reproductive strategies in birds: Reproductive effort. Amer. Natur. 111:453-478.

RoBertSON, A. 1955. Selection in animals: Synthesis. Cold Spr. Harb. Symp. Quant. Biol. 20:225-229.

Ross, H. A., AND I. A. MCLAREN. 1980. Lack of differential survival among young Ipswich Sparrows. Auk 98:495-502.

ROWLEY, I. 1983. Re-mating in birds, pp. 331-360. In P. Bateson (ed.), Mate Choice. Cambridge Univ. Press, Cambridge, U.K.

ROYAMA, T. 1966. Factors governing feeding rate, food requirements and brood size of nestling Great Tits (Parus major). Ibis 108:313-347.

Slagsvold, T. 1982. Clutch size, nest size, and hatching asynchrony in birds: Experiments with the Fieldfare (Turdus pilaris). Ecology 63:1389-1399.

STEARNS, S. 1976. Life-history tactics: A review of the ideas. Quart. Rev. Biol. 51:3-47.

VAN NoORDWIJK, A. J., A. J. VAN BALEN, AND W. SCHARLOO. 1981. Genetic and environmental variation in the clutch size of the Great Tit (Parus major). Neth. J. Zool. 31:342-372.

WINKLER, D. 1985. Factors determining a clutch size reduction in California Gulls (Larus californicus): A multi-hypothesis approach. Evolution 39:667677.

Corresponding Editor: G. de Jong 